\title{
$O$-METHYLATING ENZYMES OF DOPAMINE AND DOPAMINE DERIVED TETRAHYDROISOQUINOLINE, SALSOLINOL
}

\author{
K. IWaSa, ${ }^{*}$ M. Kamigauchi, K. Saiki, N. TaKaO and W. Wiegrebe $\dagger$
}

Kobe Women's College of Pharmacy, 4-19-1, Motoyamakita, Higashinada, Kobe 658, Japan; †Institute for Pharmaceutical Chemistry, University of Regensburg, D-8400 Regensburg, Germany

(Received in revised form 31 July 1992)

\begin{abstract}
Key Word Index - Corydalis pallida var. tenuis, C. ochotensis var. raddeana, C. incisa; Macleaya cordata; Papaveraceae; Cynanchum vincetoxicum; Asclepiadaceae; dopamine; isoquinoline alkaloids; tissue cultures; metabolism.
\end{abstract}

\begin{abstract}
By using an LC/API-MS system, it was demonstrated that dopamine condenses with acetaldehyde to give salsolinol which is further metabolized to produce 6-O-methylsalsolinol (isosalsoline) which is $O$ - and $N$-methylated to 2 provide salsolidine and $N$-methylisosalsoline, respectively, in several plant tissue cultures of Papaveraceae. Almost none of the 3-O-methoxytyramine formed from dopamine was metabolized into simple isoquinoline derivatives. Although salsolinol and 3-O-methoxytyramine were formed from dopamine, no $O$-methylatedsalsolinol was formed in tissue cultures of Cynanchum vincetoxicum (Asclepiadaceae). The results suggest that the $O$-methylating enzymes of salsolinol may be different to those of dopamine.
\end{abstract}

\section{INTRODUCTION}

It has been suggested that 1,2,3,4-tetrahydroisoquinoline (TIQ) derivatives, such as salsolinol (2), may be possible candidates for inducing parkinsonism [1] and may also have some relation to alcoholism [2]. In recent years, the neurotoxic properties of TIQs have been discussed especially with regard to Parkinson's disease. L-Dopa is used as a source of dopamine for the treatment of Parkinson's disease. It is important to elucidate the metabolism of catecholamines and TIQs in order to clarify the mechanism of the manifestation of Parkinson's disease and in the detoxication of TIQs. It has been reported that 7-Omethylated salsolinol is formed in vivo in rat brain and heart, while 6- and 7-O-methylation occurred in an in vitro experiment using a slice of rat liver [3]. In studies 1. with purified COMT from rat liver [4], it was noted that methylation of 6,7-dihydroxy-TIQ and 2-methyl-6,7dihydroxy-TIQ occurred in both the 6- and 7-positions. In preliminary reports $[6,7]$, we have demonstrated that salsolinol is metabolized by several Papaveraceae plants and tissue-cultured cells derived from these plants, to yield 6-O-monomethylated salsolinol (isosalsoline) (3) and a small amount of 6- and 7-O-dimethylated salsolinol (salsolidine) (5). In addition, 3 was $N$-methylated to provide $N$-methylisosalsoline (4). That is, $O$-methylation of salsolinol occurs in our experiments using either plants or their cultured cells at the 6- rather than at the 7hydroxyl group. The reasons why different results are obtained in vivo and in vitro in animals and between animals and plants, are not entirely clear. In this paper,

*Author to whom correspondence should be addressed. we present results which might give an answer to these questions.

Since the metabolism of salsolinol has been demonstrated in our previous studies [6,7], in this study the formation of isoquinoline alkaloids from biogenic amines and aldehyde or alcohol was examined. It has been demonstrated by TLC that salsolinol is formed by condensation of dopamine with acetaldehyde, the primary metabolite of ethanol [8]. Feeding experiments with tissue-cultured cells of Corydalis pallida var. tenuis Yatabe, $C$. ochotensis var. raddeana Ohwi, C. incisa Pers, and Macleaya cordata $\mathrm{R}$. $\mathrm{Br}$ of Papaveraceae and of Cynanchum vincetoxicum L. Pers. (Asclepiadaceae) were undertaken and the metabolites were examined by HPLC and Liquid Chromatography/Atmospheric Pressure Ionization-Mass Spectrometry (LC/API-MS) [9].

\section{RESULTS AND DISCUSSION}

\section{Experiments 1-4}

Callus tissues from $C$. pallida var. tenuis were grown on an agar medium containing dopamine. $\mathrm{CD}_{3} \mathrm{CDO}$, and DL-methionine at $25^{\circ}$ for three weeks (Table 1, Expt 1). After incubation, the medium and cells were extracted according to the method described in a previous paper [5], and the alkaloids separated by preparative TLC. Isosalsoline- $\mathrm{D}_{4}\left(3-\mathrm{D}_{4}\right)$ mixed with a small amount of salsolidine- $\mathrm{D}_{4}\left(5-\mathrm{D}_{4}\right)$ was obtained in addition to $\mathrm{N}$ methylisosalsoline- $\mathrm{D}_{4}\left(4-\mathrm{D}_{4}\right)$. The deuterium distributions of the metabolites were calculated from the ${ }^{1} \mathrm{H}$ NMR spectra to be over $90 \%$. 
Table 1. Feeding experiments in static cell cultures of C. pallida var. tenuis, C. ochotensis var. raddeana, C. incisa, M. cordata and Cyn. vincetoxicum

\begin{tabular}{|c|c|c|c|c|c|c|c|c|c|c|c|}
\hline \multirow{2}{*}{$\begin{array}{l}\text { Expt } \\
\text { no. }\end{array}$} & \multirow{2}{*}{$\begin{array}{l}\text { Cell } \\
\text { culture }\end{array}$} & \multirow{2}{*}{$\begin{array}{l}\text { Dry wt } \\
\text { of cells } \\
(\mathrm{g})\end{array}$} & \multirow{2}{*}{$\begin{array}{l}\text { Medium } \\
(1)\end{array}$} & \multicolumn{2}{|c|}{ Substrates applied } & \multirow{2}{*}{$\begin{array}{l}\text { Incubation } \\
\text { - period } \\
\text { (week) }\end{array}$} & \multicolumn{5}{|c|}{$\begin{array}{l}\text { Metabolites labelled* } \\
\text { with deuterium (mg) }\end{array}$} \\
\hline & & & & Compound & (mg) & & 2 & 3 & 4 & 5 & 6 \\
\hline 1 & C. pallida var. tenuis & 5.7 & 0.8 & $\begin{array}{l}\text { Dopamine } \\
\mathrm{CD}_{3} \mathrm{CDO} \\
\text { DL-Met }\end{array}$ & $\begin{array}{l}200 \\
200 \\
100\end{array}$ & 3 & 1 & 10.0 & 6.9 & 0.7 & I \\
\hline 2 & $\begin{array}{l}\text { C. ochotensis var. } \\
\text { raddeana }\end{array}$ & 12.1 & 0.8 & $\begin{array}{l}\text { Dopamine } \\
\mathrm{CD}_{3} \mathrm{CDO} \\
\text { DL-Met }\end{array}$ & $\begin{array}{l}200 \\
200 \\
100\end{array}$ & 3 & 5.1 & 6.2 & 2.5 & 0.4 & 1 \\
\hline 3 & C. incisa & 11.8 & 0.8 & $\begin{array}{l}\text { Dopamine } \\
\mathrm{CD}_{3} \mathrm{CDO} \\
\text { DL-Met }\end{array}$ & $\begin{array}{l}200 \\
200 \\
100\end{array}$ & 3 & 3.1 & 5.7 & 3.6 & 0.6 & 1 \\
\hline 4 & M. cordata & 8.1 & 0.8 & $\begin{array}{l}\text { Dopamine } \\
\mathrm{CD}_{3} \mathrm{CDO} \\
\text { DL-Met }\end{array}$ & $\begin{array}{l}200 \\
200 \\
100\end{array}$ & 5 & 2.2 & 3.3 & 4.1 & 0.6 & I \\
\hline 5 & C. pallida var. tenuis & 5.3 & 0.8 & $\begin{array}{l}\text { Dopamine } \\
\quad \mathrm{CD}_{3} \mathrm{CD}_{2} \mathrm{OD}\end{array}$ & $\begin{array}{l}200 \\
200\end{array}$ & 3 & 1.2 & 1.8 & 0.4 & 0.06 & 1 \\
\hline 6 & M. cordata & 3.6 & 0.8 & $\begin{array}{l}\text { Dopamine } \\
\mathrm{CD}_{3} \mathrm{CD}_{2} \mathrm{OD} \\
\text { L-Met }\end{array}$ & $\begin{array}{l}200 \\
200 \\
165\end{array}$ & 3 & 1.6 & 0.6 & 0.9 & 0.1 & l \\
\hline 7 & C. pallida var. tenuis & 7.9 & 0.8 & $\begin{array}{l}\text { 3-Methoxy- } \\
\text { tyramine } \\
\mathrm{CD}_{3} \mathrm{CDO}\end{array}$ & $\begin{array}{r}100 \\
20\end{array}$ & 3 & 1 & 0.2 & 0.04 & - & I \\
\hline 8 & C. pallida var. tenuis & 5.0 & 0.8 & $\begin{array}{l}\text { Dopamine } \\
\mathrm{CD}_{3} \mathrm{CDO} \\
\mathrm{L}-\left[\mathrm{Me}-\mathrm{D}_{3}\right] \mathrm{Met}\end{array}$ & $\begin{array}{r}114 \\
150 \\
91\end{array}$ & 3 & 1 & 2.0 & 1.3 & 0.2 & 1 \\
\hline 9 & C. pallida var. tenuis & 6.1 & 0.8 & $\begin{array}{l}\text { Dopamine } \\
\mathrm{CD}_{3} \mathrm{CDO} \\
{\left[\mathrm{Me}_{3^{-}}\right.} \\
\left.\mathrm{D}_{9}\right] \text { Choline }\end{array}$ & $\begin{array}{l}114 \\
150 \\
94\end{array}$ & 3 & / & 0.5 & trace & - & 1 \\
\hline 10 & C. pallida var. tenuis & 9.5 & 1.6 & $\begin{array}{l}\text { Dopamine } \\
\mathrm{CD}_{3} \mathrm{CDO} \\
\mathrm{L}-\left[\mathrm{Me}-\mathrm{D}_{3}\right] \mathrm{Met}\end{array}$ & $\begin{array}{l}200 \\
200 \\
165\end{array}$ & 3 & 1.9 & 4.0 & 4.4 & 0.8 & trace \\
\hline 11 & Cyn. vincetoxicum & 12.2 & 1.6 & $\begin{array}{l}\text { Dopamine } \\
\mathrm{CD}_{3} \mathrm{CDO} \\
\mathrm{L}-\left[\mathrm{Me}-\mathrm{D}_{3}\right] \mathrm{Met}\end{array}$ & $\begin{array}{l}200 \\
200 \\
165\end{array}$ & 3 & 1.5 & - & - & - & trace \\
\hline 12 & Cyn. vincetoxicum & 2.8 & 0.8 & Salsolinol- $\mathrm{D}_{4}$ & 200 & 3 & 1 & - & - & - & 1 \\
\hline 13 & Cyn. vincetoxicum & 21.0 & 3.2 & Salsolinol- $\mathrm{D}_{4}$ & 400 & 4 & 1 & - & - & - & I \\
\hline 14 & Cyn. vincetoxicum & 10.5 & 1.6 & Salsolinol- $\mathrm{D}_{4}$ & 200 & 5 & / & - & - & - & l \\
\hline
\end{tabular}

*The amounts of metabolites except for Expt 1 was calculated from the peak area in HPLC.

Similar experiments using callus tissues from $C$. ochotensis var. raddeana, $C$. incisa, and $M$. cordata were undertaken (Table 1, Expts 2-4). The fraction of watermethanol extracts after pretreatment with $\mathrm{C}_{18}$ Sep-Pak cartridge (Waters) and the tertiary-alkaloid fraction in methanol were subjected to HPLC with UV detection. Metabolites having $R_{t}$ s identical to salsolinol (2). isosalsoline (3), $N$-methylisosalsoline (4) and salsolidine (5) were detected by HPLC analysis.

The extracts were then subjected to LC/API-MS. The results obtained for standard samples of 1-6 are shown in Fig. 1. Protonated quasi-molecular ions $[(\mathrm{m} / z \mathrm{z} 154(\mathbf{1}) .168$ (6), 180 (2), 194 (3), 208 (4) and 208 (5)] each with a different $R_{t}$ value were observed for all of the compounds tested. The UV trace was a composite of the mass chromatograms (Fig. 1). In the API mass spectra, the quasi-molecular ions were observed as base peaks. Pro- tonated quasi-molecular ions ( $m / z 184,198,212$, and 212$)$, corresponding to salsolinol- $\mathrm{D}_{4}\left(2-\mathrm{D}_{4}\right), 3-\mathrm{D}_{4}, 4-\mathrm{D}_{4}$ and 5$\mathrm{D}_{4}$ were observed in the water-soluble fractions from Expts 2-4. The peaks have the same $R_{t} \mathrm{~s}$ as the standard samples shown in Fig. 1. Peaks for 3- $\mathrm{D}_{4}, 4-\mathrm{D}_{4}$ and 5- $\mathrm{D}_{4}$ were obtained for the tertiary-alkaloid fractions from Expts 2-4. The results of these experiments show that dopamine (1) condenses with acetaldehyde to produce salsolinol (2), which is metabolized into isosalsoline (3), $N$-methylisosalsoline (4), and salsolidine (5) in the tissuecultured cells of $C$. pallida var. tenuis, $C$. ochotensis var. raddeana. $C$. incisa, and $M$. cordata.

\section{Experiments 5 and 6}

Because $\mathbf{2}$ may be formed during alcohol metabolism, two feeding experiments (Expts 5 and 6) in which dopa- 

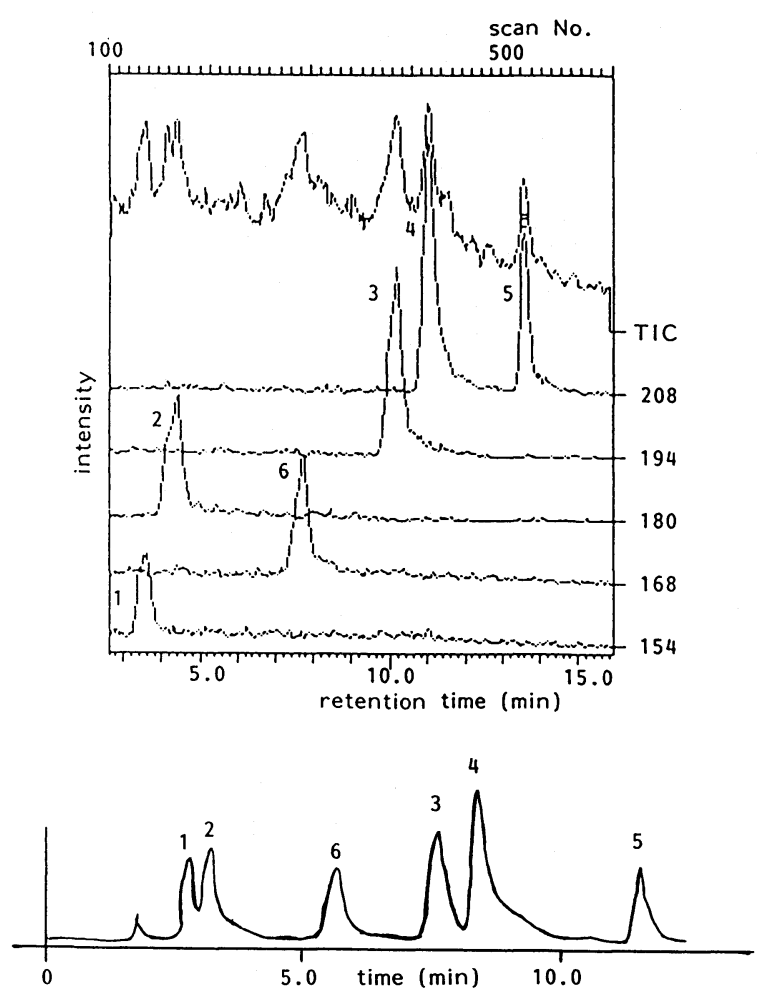

Fig. 1. Mass chromatogram of the standard samples in LC/API-MS analysis with UV detection. Upper: API-MS nebulizer temp. $260^{\circ}$, vaporizer temp. $395^{\circ}$, drift voltage 130 V. Lower: UV $280 \mathrm{~nm}$.

mine and $\mathrm{CD}_{3} \mathrm{CD}_{2} \mathrm{OD}$ were administered to tissuecultured cells of $C$. pallida var. tenuis and M. cordata were carried out. Four metabolites, 2-D $, 3-\mathrm{D}_{4}, 4-\mathrm{D}_{4}$, and 5$\mathrm{D}_{4}$, were identified by HPLC and LC/API-MS of the water-soluble extracts and the extracts containing the tertiary alkaloids.

\section{Experiment 7}

Dopamine (1) is metabolized into 3-O-methoxytyramine (6) in mammalian systems. In order to examine the possibility of the biotransformation of 6 into TIQs in plant tissue cultures, a feeding experiment with 6 and $\mathrm{CD}_{3} \mathrm{CDO}$ using cultured cells of $C$. pallida var. tenuis was carried out (Expt 7). Trace amounts of 3-D $\mathrm{D}_{4}$ and $4-\mathrm{D}_{4}$ were detected (Table 1 ). Thus 3-O-methoxytyramine was condensed to a small extent with acetaldehyde to produce TIQs.

The results from Expts 1-7 confirmed a major metabolic pathway to TIQs via salsolinol from dopamine, a neuroamine (Scheme 1). Next, $O$-methylation of dopamine and salsolinol was investigated in order to find an explanation for the difference in $\boldsymbol{O}$-methylation between animals and plants.

\section{Experiments 8 and 9}

Whether L-methionine or choline was the better methyl donor was first investigated, since choline chloride has been isolated from some Corydalis plants [10]. Dopamine, $\mathrm{CD}_{3} \mathrm{CDO}$, and $\mathrm{L}-\left[\mathrm{Me}-\mathrm{D}_{3}\right]$ methionine or $\left[\mathrm{Me}_{3}-\right.$ $\left.\mathrm{D}_{9}\right]$ choline chloride were administered to tissue-cultured cells of $C$. pallida var. tenuis (Expts 8 and 9). The $O$-methyl group at C-6 of isosalsoline and $N$-methylisosalsoline, the $O$-methyl groups at C-6 and C-7 of salsolidine, and the $N$ methyl group of $N$-methylisosalsoline were found by LC/API-MS to be labelled. The amount of $O$ - and/or $N$ methylated salsolinols produced in Expt 8 was about six times that of Expt 9. (Table 1). Therefore, L-methionine is a much better methyl donor than choline chloride.

\section{Experiments 10-14}

A feeding experiment (Expt 10) with increased amount of dopamine, $\mathrm{CD}_{3} \mathrm{CDO}$, and $\mathrm{L}-\left[\mathrm{Me}-\mathrm{D}_{3}\right]$ methionine and with the tissue-cultured cells of $C$. pallida var. tenuis was compared with an identical feeding experiment with $C y n$. vincetoxicum (Expt 11). The water-soluble extracts of Expt 10 were subjected to LC/API-MS. Salsolinol-D ${ }_{4}$ (2$\left.\mathrm{D}_{4}\right)$, isosalsoline- $\mathrm{D}_{4}$ and $-\mathrm{D}_{7}\left(3-\mathrm{D}_{4}\right.$ and $\left.3-\mathrm{D}_{7}\right), N$-methylisosalsoline- $\mathrm{D}_{4}$ and $-\mathrm{D}_{7}\left(4-\mathrm{D}_{4}\right.$ and $\left.4-\mathrm{D}_{7}\right)$, and salsolidine- $\mathrm{D}_{4}$ and $-\mathrm{D}_{7}\left(\mathbf{5}-\mathrm{D}_{4}\right.$ and $\left.5-\mathrm{D}_{7}\right)$ were identified (Table

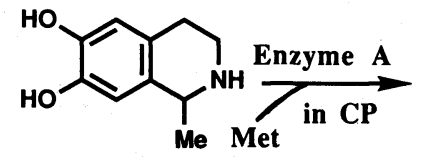

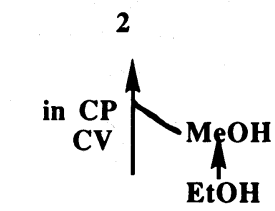

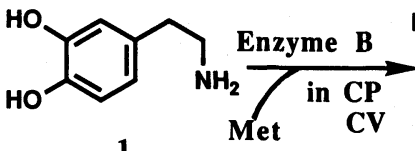

1<smiles>COc1cc2c(cc1O)[C@H](N(C)C)NCC2</smiles>
3

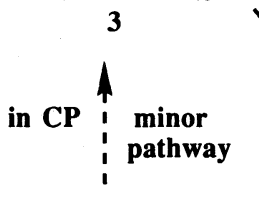<smiles>COc1cc(CCN)ccc1O</smiles><smiles>CCCCCCCCCC(C)CC</smiles>

4
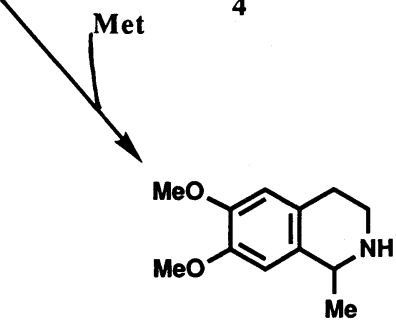

5

Scheme 1. Metabolism of dopamine in the cultured cells of $C$. pallida var. tenuis $(\mathbf{C P})$ and $C y n$. vincetoxicum $(\mathbf{C V})$. Met, methionine. The true methyl donor is almost certainly SAM. 
1, Scheme 2). Though $2-\mathrm{D}_{4}$ and 3-O-methoxytyramine$\mathrm{D}_{3}\left(6-\mathrm{D}_{3}\right)$ were identified in the cultured cells of $C y n$. vincetoxicum, no $O$-methylatedsalsolinol was detected (Table 1). In spite of varying the length of the incubation period $(3,4$, and 5 weeks) for the feeding experiments with salsolinol- $\mathrm{D}_{4}$ in Cyn. vincetoxicum (Expts 12-14), $O$ methylsalsolinol was never detected (Table 1). LC/APIMS analysis (Fig. 2) of the extract consisting of the tertiary alkaloids from $C$. pallida var. tenuis established the presence of all the above mentioned metabolites except for 2-D , plus a small amount of 6- $D_{3}, 4-D_{10}$ and 5- $\mathrm{D}_{10}$ (Table 1, Scheme 2). The ratios of the deuterated isomers of 3,4 and 5 determined by measuring the peak areas in the mass chromatogram of each isomer (Fig. 2). Only 6- $D_{3}$ was identified by LC/API-MS in the corresponding fraction from $C$. vincetoxicum.
Thus $O$ - and $N$-methylations of salsolinol and $O$ methylation of dopamine occurred in $C$. pallida var tenuis. However, although dopamine was $O$-methylated, salsolinol was not $O$-methylated in $C y n$. vincetoxicum. The L-methionine methyl group serves as the methyl donor in these methylations in C. pallida var. tenuis and Cyn. vincetoxicum. These results raise doubts about an accepted theory that the methylation of TIQs, as well as catecholamines, is catalysed by COMT. The formation of dopamine and salsolinol may well be catalysed by different $O$-methylating enzymes.

\section{CONCLUSIONS}

The metabolic pathway of dopamine was established (Scheme 1):, in cultured cells of several Papaveraceae
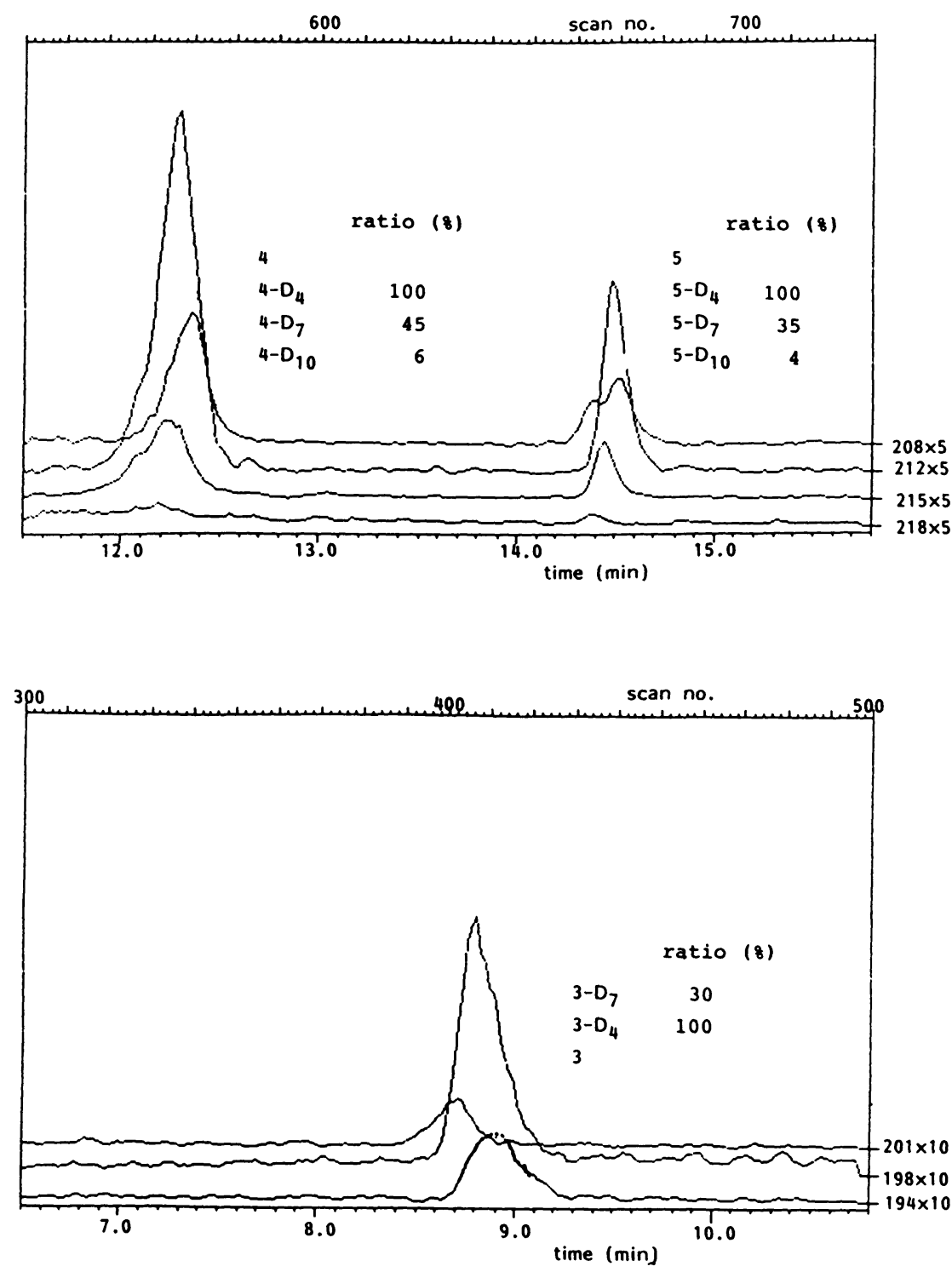

Fig. 2. LC/API-MS of the deuterated metabolites of 3,4 and 5 obtained from feeding experiment (Expt 10) with the cultured cells of Corydalis pallida var. tenuis. 


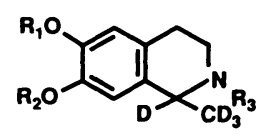

\begin{tabular}{|c|c|c|c|c|}
\hline & $\mathbf{R}_{1}$ & $\mathbf{R}_{2}$ & $\mathbf{R}_{\mathbf{3}}$ & {$[\mathrm{M}+1]^{+}$} \\
\hline 2-D & $\begin{array}{c}\mathbf{H} \\
\mathbf{M e}\end{array}$ & $\begin{array}{l}\mathbf{H} \\
\mathbf{H}\end{array}$ & $\begin{array}{l}\mathbf{H} \\
\mathbf{H}\end{array}$ & $\begin{array}{l}184 \\
198\end{array}$ \\
\hline 3-D & $\mathrm{CD}_{3}$ & $\mathbf{H}$ & H & 201 \\
\hline 4-D & $\mathbf{M e}$ & H & Me & 212 \\
\hline 4-D? & $\begin{array}{c}C_{3} \\
\mathbf{M e}\end{array}$ & $\begin{array}{l}\mathbf{H} \\
\mathbf{H}\end{array}$ & $\begin{array}{r}\mathrm{Me} \\
\mathrm{CD}_{3}\end{array}$ & $\begin{array}{r}215 \\
215\end{array}$ \\
\hline 4-D $D_{10}$ & $\mathrm{CD}_{3}$ & H & $\mathrm{CD}_{3}$ & 218 \\
\hline 5.D & $\mathbf{M e}$ & Me & H & 212 \\
\hline & $\mathrm{CD}_{3}$ & Me & $\underset{\mathbf{H}}{\mathbf{H}}$ & $\begin{array}{l}215 \\
215\end{array}$ \\
\hline 5. $D_{10}$ & C & & $\mathbf{H}$ & 218 \\
\hline
\end{tabular}

Scheme 2. Deuterated metabolites.

plants, dopamine condenses with acetaldehyde to afford salsolinol (2) which is transformed into 6-N-dimethylsalsolinol (4) and 6,7-O-dimethyl salsolinol (5) via 6-Omonomethylsalsolinol (3). Though dopamine is also metabolized into 3-O-methoxytyramine (6), it hardly condenses with acetaldehyde after 3-O-methylation to give TIQs. L-Methionine is a donor of the methyl group in the $O$ - or $N$-methylation reactions on this pathway. In Cyn. vincetoxicum (Asclepiadaceae), dopamine is methylated to provide 3-O-methoxytyramine and also condenses with acetaldehyde to give salsolinol, but salsolinol is not methylated. The L-methionine methyl group serves as the source of the methyl group in the bioconversion of dopamine into 3-O-methoxytyramine.

By comparing the $O$-methylation of dopamine and salsolinol in C. pallida var. tenuis and Cyn. vincetoxicum, it appears that the $O$-methylating enzymes of salsolinol (2) may be different with those of dopamine (1). This might be the reason why different results on the $O$ methylation are obtained in vivo and in vitro in animals and between animals and plants.

Attention should be given to the enzyme systems which are related to the metabolism of catecholamines and TIQs in vivo and in vitro. Finally, we would like to point out that LC/API-MS is a useful method for identifying trace amounts of metabolites in mammalian systems.

\section{EXPERIMENTAL}

General. ${ }^{1} \mathrm{H}$ NMR: $200 \mathrm{MHz}, \mathrm{CDCl}_{3}$; Prep. TLC: silica gel 60F 254 Merck glass plates.

Materials. All Corydalis and Macleaya cell cultures were derived from the stem or root on Murasige and Skoog's (MS) medium containing 2, 4-dichlorophenoxyacetic acid $\left(1 \mathrm{mg} \mathrm{l}^{-1}\right)$, kinetin $\left(0.1 \mathrm{mg} \mathrm{l}^{-1}\right)$, yeast extract $(0.1 \%)$, and agar $(1 \%)$ during $1974-1989$. Cell cultures of Cynanchum vincetoxicum were derived from the stems of plants harvested at the Regensburg University botanical garden (Germany) in 1983. The callus tissues were subcultured every 3 or 4 weeks onto fresh MS medium at $25^{\circ}$ in the dark. [1-D, $\left.M e-\mathrm{D}_{3}\right]$ Salsolinol $\left(2-\mathrm{D}_{4}\right)$ was prepared according to the method described in a previous paper [6]. $\mathrm{L}-\left[\mathrm{Me}-\mathrm{D}_{3}\right]$ methionine $(99 \%)$ and $\left[\mathrm{Me}_{3}-\mathrm{D}_{9}\right]$ choline chloride $(\mathbf{9 8 . 8} \%$ ) were purchased from Aldrich (U.S.A.) and MSD Isotopes (Canada), respectively.

Callus cultures and extraction. Feeding experiments were undertaken under the procedure as described in ref. [6]. The conditions and the amount of metabolites isolated are shown in Table 1. Extraction and work-up was as described in ref. [5]. $\mathrm{H}_{2} \mathrm{O}-\mathrm{MeOH}$-soluble extracts were concd and passed through $\mathrm{C}_{18}$ Sep-Pak cartridge (Waters) and the cartridge washed with $\mathrm{MeOH}-\mathrm{H}_{2} \mathrm{O}$. The washings were subjected to HPLC or LC/API-MS. The tertiary-alkaloids fraction was dissolved in $\mathrm{MeOH}$ and the MeOH soln subjected to HPLC or LC/API-MS.

HPLC or LC/API-MS analysis. HPLC was performed using a Cosmosil $5 \mathrm{C}_{18}$-AR $(4.6$ i.d. $\times 150 \mathrm{~mm})$ reversedphase column in which the temp. was maintained at $40^{\circ}$. The HPLC conditions were as follows: flow rate $1 \mathrm{ml}$ $\min ^{-1}$, UV $280 \mathrm{~nm}$, mobile phase $0.1 \mathrm{M} \mathrm{NH}_{4} \mathrm{OAc}$ adjusted to $\mathrm{pH} 4.0$ (A), $0.1 \mathrm{M} \mathrm{NH}_{4} \mathrm{OAc}$ adjusted to $\mathrm{pH} 5.3$ (B), $\mathrm{MeOH}$ (C). Gradient I: B and C; initial $7 \%$ of B, 5 min $14 \%$ of $B, 15 \min 50 \%$ of $B, 2$ from water-soluble fractions of Expts 1-6, 10, and 11: 3.7-4.0 min (standard, $3.8 \mathrm{~min}$ ), 6 from water-soluble fractions of Expts 10 and 11: 7.1 and $6.9 \mathrm{~min}$ (standard, $6.9 \mathrm{~min}$ ). Gradient II: $B$ and C; initial $10 \%$ of B, 5 min $10 \%$ of B, $15 \min 60 \%$ of B, 3 from tertiary-alkaloid fractions of Expts 1-10: 4.8-5.0 min (standard $5.0 \mathrm{~min}$ ). 4 from tertiary-alkaloid fractions of Expts 1-10: 6.0-6.4 min (standard $6.1 \mathrm{~min}$ ), 5 from tertiary-alkaloid fractions of Expts 1-10: 11.8-12.8 min (standard, $11.9 \mathrm{~min}$ ). Gradient III: A and C; initial 10\% of B, 5 min $10 \%$ of B, 15 min $60 \%$ of B; 3-5 from tertiaryalkaloid fractions of Expts 1-10:6.2-7.2 min (standard, 6.3-6.9 $\mathrm{min}$ ), 6.9-8.0 $\mathrm{min}$ (standard, 7.2-7.8 $\mathrm{min}$ ), 14.5-15.9 min (standard, 14.8-15.3), respectively. Quantitation of each metabolite was carried out by comparison of its peak area with the calibration curve of the standard. LC/API-MS analysis: nebulizer and vaporizer temps were determined to be $260^{\circ}-280^{\circ}$ and $395^{\circ}$, respectively. Drift voltage was $130-160 \mathrm{~V}$. The quasi-molecular ions were monitored in Scan Mode or Selected Ion Monitoring (SIM) method. The column was a reverse-phase column, Cosmosil $5 \mathrm{C}_{18}$-AR $(4.6$ i.d. $\times 150 \mathrm{~mm})$. The mobile phase was $0.1 \mathrm{M} \mathrm{NH}_{4} \mathrm{OAc}$ containing TFA (pH 5.3), to which $\mathrm{MeOH}$ was added under the linear gradient (from 7 to $50 \%$ ) over a $15 \mathrm{~min}$ period. The flow rate was 1

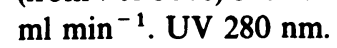

Acknowledgement-Kinuko Iwasa thanks the Alexander von Humboldt Foundation, Bonn, Germany, for a scholarship.

\section{REFERENCES}

1. Nagatsu, T. and Yoshida, M. (1988) Neurosci. Letters 87, 178.

2. Collins, M. A. and Bigdeli, M. G. (1975) Life Sci. 16, 585. 
3. Origitano, T. G. and Collins, M. A. (1980) Life Sci. 26, 2061.

4. Creveling, C. R., Morris, N., Shimizu, H., Ong, H. H. and Daly, J. (1972) Molec. Pharmacal. 8, 398.

5. Iwasa, K., Kamigauch, M. and Takao, N. (1987) Arch. Pharm. 320, 693.

6. Iwasa, K., Kamigauchi, M. and Takao, N. (1991) Phytochemistry 30, 2973.
7. Iwasa, K., Kamigauchi, M. and Takao, N. (1992) $J$. Nat. Prod. 55, 491.

8. Zarrang de Ysern, M. E. and Ordonez, L. A. (1981) Prog. Neuropsychopharmacol. 5, 343.

9. Sakairi, M. and Kambara, H. (1988) Anal. Chem. 60, 774.

10. Tani, C., Nagakura, N. and Hattori, S. (1975) Yakugaku Zasshi 95, 1103. 